\title{
THE IMPLEMENTATION OF ISLAMIC STORY METHOD IN INSTILLING RELIGIOUS MORALS IN EARLY CHILDHOOD IN TK TAAM ADINDA KEPATIHAN MENGANTI GRESIK
}

\author{
Muhammad Syaikhon \\ PGPAUD, FKIP, Universitas Nahdlatul Ulama Surabaya \\ muhammadsay87@unusa.ac.id
}

\begin{abstract}
This is a field research using a descriptive qualitative approach and titled The Implementation of Islamic Story Method in Instilling Religious Morals in Early Childhood in TK TAAM Adinda Kepatihan Menganti Gresik. It is aimed at describing the implementation of Islamic story method in instilling religious morals in TK TAAM Adinda Kepatihan Menganti Gresik in addition to supporting teachers involved in the implementation. The research findings can be concluded that the implementation of Islamic story method in instilling religious morals in TK TAAM Adinda Kepatihan Menganti Gresik consists of preparation, material, method, media, and evaluation. In terms of preparation, teachers have done various personal and technical preparations. In terms of material, teachers started it through a model of Gallup education development so-called RPPM (Rencana Pelaksanaan Pembelajaran Mingguan/ weekly learning implementation plan) and RPPH (Rencana Pelaksanaan Pembelajaran Harian/daily learning implementation plan) as a result of the 2013 curriculum development that contains creed, syari'a, and morals. In terms of method, teachers always used various interesting ways. In terms of media, teachers often used audio and visual media rather than storybooks and slates. In terms of evaluation, teachers did it by using a question and answer method and observation, and holding dialogues with student guardians. The implementation of Islamic story method in instilling religious morals in TK TAAM Adinda has such supporting factors as teachers, environment and the learning process. In addition, the implementation also has such barriers as inadequate time, class management, and inadequate tools to tell stories.
\end{abstract}

Keywords: Implementation, Islamic Story Method, Early Childhood 


\section{INTRODUCTION}

In the world of education, methods are very necessary and considerably influential in achieving a learning success. The learning method will be easy and fun. Therefore, in every learning, very appropriate methods are absolutely needed, so that it does not seem to be boring. Although there are many learning methods, not all of them could be applied in a variety of learning. In this context, teachers must be able to consider which learning methods are appropriate and good to use. Especially for the learning in early childhood, the method must be really interesting and enjoyable for students. (Fadhilah, 2012: 162)

The method of telling stories or fairy tales is one of the ways to provide learning experiences for children to get a better mastery of the contents of the told stories. Through stories, children can absorb the messages through storytelling activities littered fully with information or values and inspiring children to apply such vales in their daily life. (Moeslichatoen, 2004: 170)

Educating and teaching children by giving examples is more effective than advising them. Implicitly, fairy tales or stories are forms of teaching that provide concrete examples to children through story characters. Through a story, teachers can introduce the morals and figures of good and pious Muslims. Thus, storytelling can play an important role in the process of forming the children characters.

In the learning process at TK TAAM Adinda Kepatihan Menganti Gresik, students are given general and religious learning materials. One method used is the story one. This method is more often used in introducing materials. Based on the fact that at the time of introducing the story, especially Islamic exemplary stories, the students were very enthusiastic about listening to the stories. In other words, the story method is the main method that is applied in the implementation of learning in TK TAAM Adinda Kepatihan Menganti Gresik.

From the description above, the writer is interested in studying more about the implementation of the story method in the process of instilling religious morals in early childhood through a study entitled "The Implementation of Islamic Story Method in Instilling Religious Morals in Early Childhood at TK TAAM Adinda Kepatihan Menganti Gresik".

\section{RESEARCH PROBLEM}

Studying more about the implementation of the islamic story method, and the supporting and inhibitors for infusing moral religion in TK TAAM Adinda Kepatihan Menganti Gresik.

\section{THEORY}


Storytelling (storytelling) is a technique for giving stories to children. Storytelling is the best way to communicate story messages that contain ethics, morals, and religious values. Besides being beneficial for the development of personality, morality, and morality of children, storytelling can also be beneficial for improving children's language development. From an early age, children get a variety of knowledge stories that enrich and enhance cognitive abilities, memory, intelligence, intelligence, and language creativity. (Agoes Dariyo, 2011: 161)

By listening to a story, the sensitivity of the soul and feelings of students can be moved, imitate good figures that are useful for the benefit of the people, and hate someone wrong. So, by providing stimulation to students with the story, it automatically encourages students to do good and can form noble morals, and can nurture spiritually.(Muhaimin dan Abdul Mujib, 1993: 260)Earl V. Pullias and James D. Young, said that:

One of the qualities of the good storyteller is that he knows how to use the experiences and ideas of his listeners as a starting point, from which to lead them into adventures in the past, to new understandings of the present, and to vision, which may become the future. He excites and awakens the dreams, longings, and urgings of his listeners and guides them into thinking. The good storyteller knows how to use his voice well, when to speak quickly or slowly, loudly or quietly. He also knows how to look at his listeners. He does more than look up or look toward them. He look at their eyes, showing his listeners that he know that they are there, that he is concerned about them. (Earl V. Pullias and James D. Young, 2000: 108-109)

There are several kinds of storytelling techniques that can be used include:

a. Read straight from the storybook

b. Tell stories by using illustrations from books

c. Telling fairy tales

d. Tell stories using a flannel board

e. Tell a story using a doll

f. A dramatization of a story

g. Tell stories while playing the fingers.(Moeslichatoen, 2004: 158-166)

Among the benefits of the story for early childhood are as follows.

a. Building inner contact between children and their parents and children and their educators.

b. Media to deliver messages to children.

c. Children's imagination or fantasy education

d. It can train the emotions or feelings of children.

e. Help the process of self-identification (deeds).

f. Enriching the inner experience.

g. It can be entertainment or attract the attention of children.

h. Can form a child's personality. (Fadhilah, 2012: 174-175) 
The steps for implementing the story method according to Moeslichatoen are:

a. Communicating goals and themes in activities tell the child.

b. Set the seat so that you can listen with clear intonation.

c. Opening the storytelling activities, educators explore children's experiences by the theme of the story.

d. Development of stories told by educators. Educators present facts around the child's life according to the theme

e. Closing the storytelling activity by submitting questions related to the content of the story. (Moeslichatoen, 2004: 179)

\section{Paradigm and Teoretic Model}

Aqeedah educational materials are presented in the form of telling stories, including the ones of prophets and apostles. From the story material, teachers must be able to choose a story that fits the theme. The story to be told must also have an educational element that is appropriate to the child development and can be a motivation and role model for students to have good morals.

\section{Research Approach}

This is field research using a qualitative descriptive approach. This research seeks to examine deeply and explain the implementation of the Islamic story method in infusing religious morals in early childhood in TK TAAM Adinda Kepatihan Menganti Gresik. Sources of data obtained were through observation and interviews with foundation administrators, teachers, students, parents and related parties. Data collection techniques were carried out through observation, in-depth interviews, and documentation. Data analysis was carried out in three stages, namely data reduction, data display, and conclusion drawing /verification.

\section{Results and Discussion}

\section{The Implementation of Islamic Story Method in Instilling Religious Morals in TK TAAM Adinda Kepatihan Menganti Gresik \\ a. Preparation}

Preparation in the learning process includes personal preparation, namely preparing the overall body condition and sound as well as deepening materials and technical one, consisting of media, stationery, RPPM (Weekly Learning Implementation Plan), and RPPH (Daily Learning Implementation Plan). Preparation is needed in the context of the stability and the effectiveness of learning process, especially technical preparation. The preparation of the learning process is more directed and run smoothly through the well-designed preparation. In the personal preparation, deepening materials is also needed by reading, understanding the messages contained in the story, even memorizing it. 
To start telling a story, a teacher usually asks the characters in the story or what pictures the students see are covered in front of the storybook if the story uses the storybook media. Then the teacher tells the story in a varied tone of voice, sometimes fast and sometimes slow and shows facial expressions describing the feelings of the characters in a story, for example sad, happy or evil expressions so that students are enthusiastic in listening to stories that are delivered so that the stories can be understood and provide an example for students. If the media uses audiovisual stories, the teacher only needs to condition the students and shows the story through the LCD. If students feel bored listening to the story being told, the teacher stops the story by doing movements and singing a song or by clapping silently so that students focus on listening to the story again.

To close the story, the teacher concludes the story being told and explains the message of the story. The teachers also asks questions related to the content of the story, sometimes with their guidance, the teachers ask some students to retell the story. Before greeting, the teacher gives motivations to students to hold the messages from the story.

\section{b. Theory}

Aqeedah educational materials as explained above are presented in the form of telling stories, including the ones of prophets and apostles. From the story material, teachers must be able to choose a story that fits the theme. The story to be told must also have an educational element that is appropriate to the child development and can be a motivation and role model for students to have good morals. In general, the material above is following the learning program at TK TAAM Adinda focusing on two fields, namely the development of talents and interests and the development of basic abilities. Teachers have also made preparations by picking out materials that are appropriate to the child development, especially in TK TAAM Adinda.

\section{c. Method}

To instill religious morals, TK TAAM Adinda uses methods that are appropriate to the development of their students in the hope that after being taught these materials can be memorized so that the children can be able to practice in their daily lives. The method used to achieve this goal is the Islamic one.

The story method is a practical way or effort in the formation and preparation of students. In turn, this method is very effective to be applied in the hope that strong characters can be formed in each student especially those related to religious morals through materials taught in schools.

However, this story method will not reap maximum results without the support of other methods. Because basically all methods have advantages 
and disadvantages. One method used in addition to the story in TK TAAM Adinda is the exemplary method. This method is a key element of instilling religious morals for being capable of showing moral behaviors in good religious life by observing and imitating the behaviors of their teachers and parents. They consider teachers to be role models with strong behaviors. If teachers have polite and responsive behaviors, they will be role models for their students.

So in TK TAAM Adinda, there is an integration of the Islamic story method with others to support the implementation of the story method itself. Consequently, the desired goal can be achieved optimally.

The story method is a very effective way of learning while the purpose of the story method in TK TAAM Adinda is to build a foundation of faith and strong piety of students. This Islamic story method can expectedly prevent negative impacts for students along with the rapid development of science and technology in the present and future.

\section{d. Media}

The media used by teachers in the implementation of story method includes storybooks, audiovisuals, and blackboards. All of these media are used by teachers as a complement to the story method and the use of media is very effective in making students interested in and enthusiastic about listening to stories. In learning, media becomes one of the important elements in the learning process. Through the media, the messages contained in the story can be absorbed well by students. In this case, the use of media in TK TAAM Adinda in implementing the story method is good enough. The audiovisual media is also used.

\section{e. Evaluation}

After the preparatory stage, until the implementation of the story method was carried out, the teachers in TK TAAM Adinda conducts an evaluation. The evaluation (assessment) phase is done by using a question and answer technique between teachers and students to find out how far they know and understand the contents of the story. In addition, the teachers also observe the behavior of students in participating in daily learning activities at school.

At each end of learning process, the teachers will review what they do and those participating in learning activities properly, such as when praying and memorizing short letters or asma'ul husna, saying politely, paying attention and doing a good job.

Then the teachers will give a good star score to each student according to what they do. The good stars they collect every day and every weekend will be exchanged with gifts in the form of food, toys and others. With the good 
star the students will be more motivated to have morals which are good, including the habituation inspired from the story to be applied in their daily lives.

Educational values that are embedded in children are the first. These values of faith are introduced to children by:

a. Introducing the name of Allah SWT and His Messengers

b. Giving a picture of the one creating this universe through exemplary stories, and

c. Introducing the Glory of God.

Second, the values of worship. Worship is tangible evidence for a Muslim in believing and guiding the Islamic creed. In this case, teachers introduce the values of worship by telling stories to children about people who believe and always carry out worship according to God's rules and commandments. The value of religious education for children will make it a habit to carry out obligations such as performing five prayers.

Third, the moral values instilled in children are to form humans who have awareness in carrying out religious teachings. Teachers explain what is good and what is bad. Various misbehaviors can be reduced through the inculcation of good behaviors and traits by imitating the characters or behavioral traits in the story. Storytelling has a better effect than directing children though such violences as hitting, pinching, tweaking, yelling and so on.

Fourth, psychological values; children are very happy and feel happy after getting the stories from their teachers. They could create a fun atmosphere, even inspire children to retell creatively to their parents.

2. Supporting and Inhibiting Factors in the Implementation of Islamic Story Methods in TK TAAM Adinda Kepatihan Menganti Gresik.

The implementation of the story method in TK TAAM Adinda has several supporting factors and also obstacles that make the school activities run less smoothly. Among the supporting factors include:

\section{a. Teacher}

The TK TAAM Adinda teachers have had the experience because they have long been in the world of children, some have also studied education in universities.

\section{b. Environment}

The students come from a religious community and have been given a stimulus from their families about the need for knowledge. Thus the enthusiasm to follow the story is also high.

\section{c. Learning Resources}


Teachers easily obtain learning resources, namely books that contain story material. They can get it even from street vendors, magazines, and so on.

Among the inhibiting factors include:

\section{a. Time Barriers}

Time becomes an obstacle for teachers in telling stories because the time to tell stories sometimes shift, especially when the students' playtime is quite a lot, so when they enter the classroom the play activities are still continuing.

\section{b. Class Management}

Related to the class management, sometimes teachers still meet problems, so they arrange children seating position so that they can be conditioned calmly and ready to listen to the story to be told.

\section{c. Barriers to Storytelling Tools}

In terms of tools used in storytelling activities, teachers often use storybook media because it is easy to get. While storytelling tools such as audio and audiovisual are rarely used because the numbers are limited and not all teachers can operate them. From the several supporting and inhibiting factors, the implementation of learning in TK TAAM Adinda Kepatihan Menganti Gresik still meets other factors. But the teachers in TK TAAM Adinda remain committed to carrying out learning seriously, especially related to the story method and generally with other methods.

\section{CONCLUSIONS AND SUGGESTIONS}

Based on research conducted at TK TAAM Adinda Menganti Gresik, it can be concluded as follows:

1. The implementation of Islamic story method in instilling religious morals in TK TAAM Adinda Kepatihan Menganti Gresik consists of preparation, material, method, media, and evaluation. In terms of preparation, teachers have done it through a variety of personal and technical preparations. In terms of material, teachers do this by starting with an educational development model that is driven by the RPPM (Weekly Learning Implementation Plan) and RPPH (Daily Learning Implementation Plan) as a result of the development of the 2013 curriculum which contains aqeedah, sharia, and morals. In terms of method, teachers always use various interesting ways. In the case of media, teachers more often use picture book media than audiovisual one. In terms of evaluation, teachers do it by using a question and answer method and observation, as well as holding a dialogue with student guardians. 
2. The implementation of Islamic story method in instilling religious morals in TK TAAM Adinda has such supporting factors as teachers, the environment and learning resources. In addition, the implementation of this method also has inhibiting factors including time, class management, and inadequate tools for storytelling.

\section{SUGGESTION}

The writer's recommendations are as follows:

1. For teachers, especially the teachers in TK TAAM Adinda Menganti Gresik, they need to always develop and improve the learning programs using Islamic story method so that they could produce an Islamic generation.

2. For students, they need to develop religious morals by getting used to listening and reading Islamic stories so that any learning process could be attached to students.

3. For researchers, the results of this study could be used as a reference for subsequent studies related to the implementation of Islamic story method in instilling religious morals in early childhood (AUD).

\section{REFERENCES}

Abdullah, Shodiq, Evaluasi Pembelajaran Konsep Dasar, Teori dan Aplikasi, Semarang: Pustaka Rizki Putra, 2012.

Abdullah bin Muhammad bin Abdurrahman Alu Syaikh, Tafsir ibnu Katsir, Terj. M. Abdul ghofar, Jakarta: Pustaka Imam Asy-Syafii, 2008.

Abuddin, Nata, Perspektif Islam Tentang Strategi Pembelajaran, Jakarta: Kencana, 2009.

Ahmad Mustafa Al-Maragi, Tafsir Al-Maragi,Terj. Hery Noer Aly, Karya Toha Putra, 1994, Juz XIII.

Ahmad, Syar'I, Filsafat Pendidikan Islam, Jakarta: Pustaka Firaus, 2005.

Ardy Wiryani, Novan, Bina Karakter Anak Usia Dini, Yogyakarta: Ar-Ruzz Media, 2014.

Arif, Armai, Pengantar Ilmu dan Metodologi Pendidikan Islam, Jakarta: Ciputat Pers, 2002.

Assegaf Abd. Rachman, Filsafat Penidikan Islam, Jakarta: Rajawali Pers, 2011.

Athiyah Ath-Thuri, Hannan, Mendidik Anak Perempuan di Masa Kanak-kanak, Jakarta: Amzah, 2007.

Daradjat, Zakiah, Ilmu Jiwa Agama, Jakarta: Bulan Bintang, 2005.

Dariyo, Agoes, Psikologi Perkembangan Anak Tiga Tahun Pertama, Bandung: PT Refika Aditama, 2011.

Departemen Agama RI, Al-Qur'an dan Tafsirnya, Jakarta: Lentera Abadi, 2010. Departemen Agama RI, Al-Qur'an dan Terjemahnya, Jakarta Timur: Bumi Aksara, 2002.

Dimyati dan Mujiono, Belajar Dan Pembelajaran, Bandung: Alfabeta, 2008. 
Earl V. Pullias dan James D. Young, A Teacher is Many Things, Greenwich: Faweett Publication Inc, 2000.

Fadhilah, Muhammad, Desain Pembelajaran Paud, Jogyakarta: Ar Ruzz media, 2012.

Fauziddin, Mohammad, Pemebelajaran Paud, Bandung: PT Remaja Rosdakarya, 2014.

Hartati, Netty, dkk., Islam dan Psikologi, Jakarta: PT Raja Grafindo Persada, 2005.

Hasan, Maimunah, PAUD, Jakarta: Diva Press, 2009.

Helmawati, Pendidikan Keluarga: Teoretis dan Praktis, Bandung: Remaja Rosdakarya, 2014.

Husein, Abdur Rozak, Hak dan Pendidikan dalam Islam, Jakarta: PT Fikahati Aneska, 1992.

Ramdhan, Tri Wahyudi. "Model Pengembangan Kurikulum Multikultural." Jurnal Al-Insyiroh: Jurnal Studi Keislaman 5.2 (2019).

Mansur, Pendidikan Anak Usia Dini dalam Islam, Yogyakarta: Pustaka Pelajar, 2009.

Junaidi. "Model Pendidikan Multikultural." Al-Insyiroh: Jurnal Studi Keislaman 2.1 (2018): 57-72.

Majid, Abdul dan Aziz, Abdul, Mendidik Dengan Cerita, Bandung:PT Remaja Rosdakarya, 2008.

Margono, Metodologi Penelitian Pendidikan, Jakarta: Rineka Cipta, 1997.

Moeslichatoen, Metode Pengajaran Di Taman Kanak-kanak, Jakarta: PT Rineka Cipta, 2004.

Moleong, Lexy J, Metodologi Penelitian Kualitatif Edisi Revisi, Bandung: PT Remaja Rosda Karya, 2010.

Muhaimin dan Mujib, Abdul, Pemikiran Pendidikan Islam, (Bandung: Trigenda Karya, 1993.

Mulyasa, Kurikulum Berbasis Kompetensi, Bandung: Remaja Rosdakarya, 2004.

Manajemen PAUD, Bandung: PT Remaja Rosdakarya, 2012. 